\title{
指定券自動発売機におけるマン・マシンの研究“
}

\section{吉岡 哲二**}

\section{1. はじめに}

自動券売機は清涼飲料などの自動販売機とともに大幅 に普及し，現在では主要鉄道***だけでも 1 万台を超え ており, 近距離キップの発売は自動券売機といった考え 方が広く一般に定着しつつある.

最近の自動券売機は, 機能的にも高度化が進みマイコ ンの制御により券面印刷, 運貨計算, つり銭の補給など コンピュータ技術が広く活用されている.

今回紹介する指定券自動発売システムは, 中央のマル ス****・コンピュータと直結した端末機としての広域な 自動発売システムであり，従来の“みどりの空口”で， 係員の操作により行っていた指定券者，利用者自身の操 作によって発売しようとするものである.

システム開発のうち，マン・マシンに関連する部分の 検討結果を紹介し，最後にシステムの効率化のために， 人間工学の面からの検討の必要性について述べる.

\section{2. 入力方式の検討}

指定券の購入は，列車の座席確保を目的として，予約 券を事前に入手するケースが多く，指定券自動発売機が 市中のホテルロビーなどに設置されれば，購入のため に，わざわざ駅に出向かなくても済む便利さがあり，ま た，銀行のオンライン・システムによる預金支払機（以 下 $\mathrm{C} \cdot \mathrm{D}$ という）と同樣に，時間外の利用か可能となる メリットも期待できる.

てのような利便性が予想されるためか, アンケート調 查により指定券の自動発売機の開発についての賛否を求 めると賛成意見が意外に多いのである.

しかし，指定券は，一般のキップと異なり，乗車日な

* 昭和55年10月29日受付

** 鉄道学㗢科学研究所

Railway Labour Science Research Institute.
ど多くの購入条件を機械に入力する必要があり,さら に，すべての条件が正確に入力されても満席による発売 不能のケースもある.

このため, 機械への入力方法が問題となり，表 1 亿示 す 3 方式について検討を行った。

\section{2-1. OMR方式}

ての方式は, 申込書に代えて，OMR カードを備えて おき，てのカードに購入条件をマークし，カードを機械 に挿入する方式である.

OMR カードは, オフラインで記入するため，機峨の 占有時間は短く，カードの種類を多く準備するととによ ク，1台の装置で全国の列車に対応できるメリットがあ ろ.

しかし, OMR カードの記入という事前準備と記入の 信頼性が問題となる.

\section{2-2. 押ボタン方式}

ての方式は，従来の券売機と同じょうに，接客面にボ タンを並へてて，必要なボタンを押して入力する方式で， 操作マナーは一般に普及している反面, ボタンの数が多 く，その選択に時間がかかる欠点があり，配列するボタ ン数にも限度がある.

\section{2-3. テンキー方式}

この方式は， 10 個の数字ボタンのみで入力する方法 で,すへての購入条件をコード化して行うため, 入力順 序を正確に行うことが前提となり，電話予約方式と似た 方法であり, 入力に時間がかかるなどの欠点がある.

ての 3 方式について, 図 1 に示すモックアップを用い て操作性の実験を行うとともに接客面デザィンについて

*** 日本鉄道サイバネテックス協議会加盟の鉄道会社など

**** 指定券発売用磁気電子自動予約システムの略 (MARS : magnetic electronic automatic seat reservation system) 


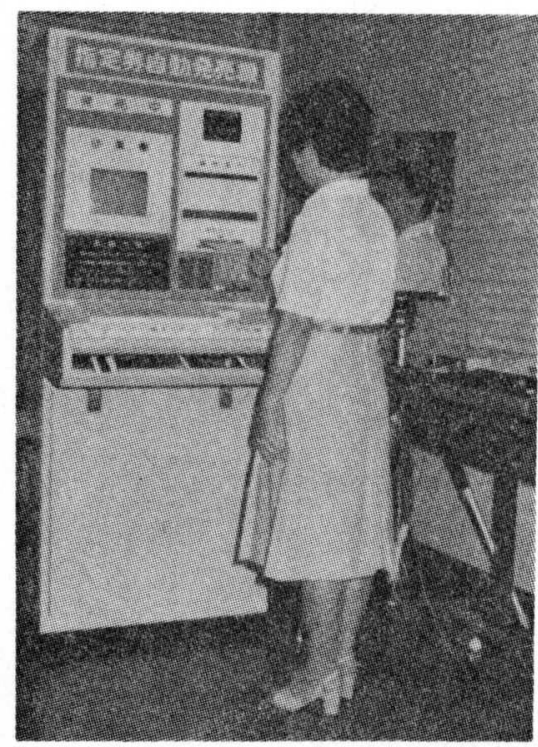

図 1 モック・アップによる実験風景

\section{も検討を行った.}

結論としては，3 方式それぞれ特徽があり特定区間の 専用型としては, 押しボタン方式が優れている.また, 1 台の機械で全国の列車に対応する多能型としては, 所 要時間の面からも OMR 方式が最も罗当と考えられる.

なお，音声入力方式や $\mathrm{OCR}$ 方式などについても検討 したが，現在の関連技術の開発状況などから 3 方式に限 定して研究をすすめた。
以下, 主として OMR 方式による多能型について述べ る.

\section{O M R カード記入に関する検討}

OMR カードの記入は, 現在, 国立大学などの共通一 次試験, 会社の採用試験, 国势調查などにおいて用いら れ, 一般に普及の傾向にあるが, 自動販売機に OMR カ ードを用いたシステムは，その例はなく不安な面もあっ たので記入に関する信頼性のテストを行った.

また，指定券購入条件を 1 枚の OMR カードにまとめ てデザインする場合の全国列車群の区分けやカードの大 きさ，文字の配列などについて種々の検討を行って改良 を加えてきた。図 2 は 3 次試作の新幹線用 OMR カード である.

OMR カードの 1 次武作では約 300 名, 2 次試作では 約 1,200 名を対象に記入テストを配票形式で実施した。

テストの結果, エラーの発生率は, 図 3 に示すとおり で, エラーの原因別発生率は, 表 2 亿示すとおりである.

記入エラーのおもなものは，記入もれでありその要因 を分析してみると, 記入要領がわからない場合, 失念に よる記入もれの場合, 必要を慧めないための記入もれの 場合に分けられる.

第 1 希望に限定してみると $84 \%$ が完全に記入されてい た. 記入要領のわかりやすさと, カードの様式には大き な関連があり，様式の改良により記入エラーを少なくす るととができた。

表 1 指定券自動発売装置の入力方式別システム評価

\begin{tabular}{c|l|l|l|l|l|l|l|l|l}
\hline $\begin{array}{l}\text { 項目 } \\
\text { 入力時の } \\
\text { 方式 }\end{array}$ & 問題点 \\
\hline
\end{tabular}




\begin{tabular}{|c|c|c|c|}
\hline 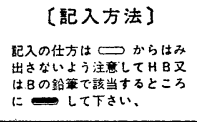 & \multicolumn{3}{|r|}{ 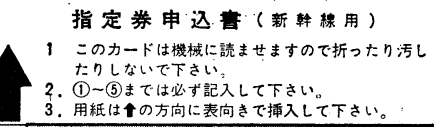 } \\
\hline 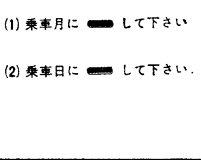 & & \multicolumn{2}{|c|}{ 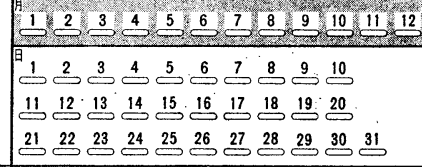 } \\
\hline 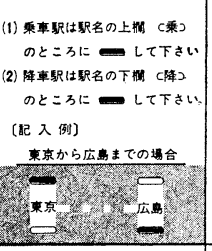 & & \multicolumn{2}{|c|}{ 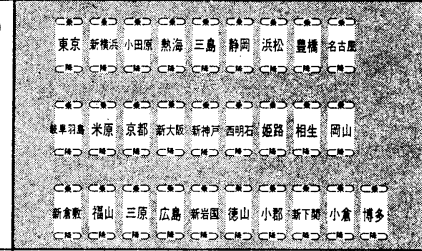 } \\
\hline 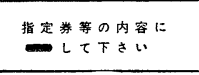 & & \multicolumn{2}{|c|}{ 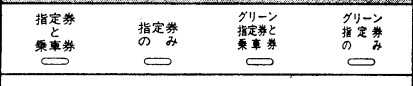 } \\
\hline & & \multicolumn{2}{|c|}{ 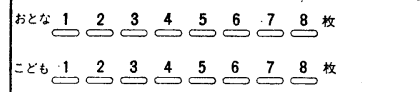 } \\
\hline \multirow{2}{*}{ 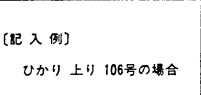 } & & \multicolumn{2}{|c|}{ 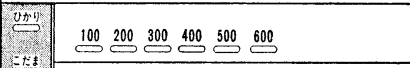 } \\
\hline & & \multirow{2}{*}{ 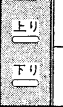 } & 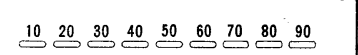 \\
\hline 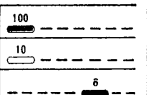 & & & $133^{3} \omega^{5} b^{6} \underbrace{8} g^{9}$ \\
\hline \multirow{3}{*}{$\begin{array}{l}\text { 第 } 2 \text { 希望の列車があり } \\
\text { ましたら、第 } 1 \text { 希望と } \\
\text { 同じ要領で眍入して下 } \\
\text { さい。 }\end{array}$} & & \multirow{3}{*}{ (wing } & $100200300 \stackrel{400}{ } \stackrel{500}{=} 600$ \\
\hline & & & $10 \stackrel{20}{=} \leftrightarrows 4050 \quad 60708090$ \\
\hline & & & \\
\hline
\end{tabular}

図 $2 \mathrm{OMR}$ 申込カード（意匠登録申請）

表 2 原因別エラー発生件数（2次）

\begin{tabular}{c|c|c|c}
\hline 原因 エラー & 発生件数 & 発生率 $(\%)$ & 割合 (\%) \\
\hline 記入もれ & 396 & 16.0 & 59.5 \\
\hline 重 複 記 入 & 47 & 1.9 & 7.1 \\
\hline 記入欄相違 & 168 & 6.8 & 25.3 \\
\hline 解 釈 相 違 & 6 & 0.2 & 0.9 \\
\hline 消方不適正 & 48 & 1.9 & 7.2 \\
\hline 合 計 & 665 & 26.9 & 100.0 \\
\hline
\end{tabular}

注）発生率は 2,472 枚を対象とした（除く問題無視） エラー発生件数は 1 枚のカードの中に重複したも のはそれぞれ計上した

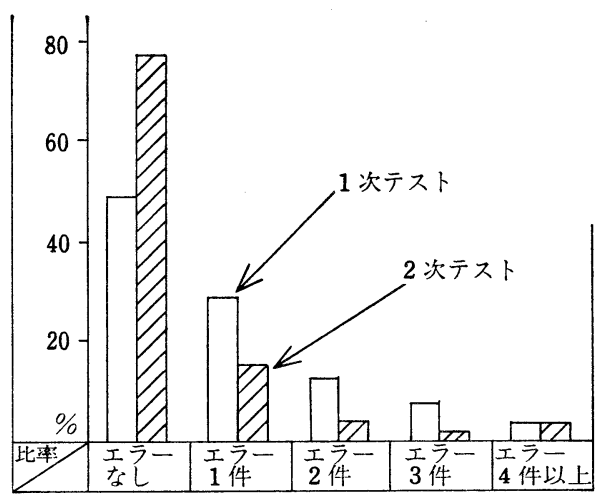

図 3 記入テストの結果

次に, 記入の仕方については, コンピュータに入力し た結果，リゼクトされた件数はきわめて少なく， $1.3 \%$ 程度であり, 光学読み取りの精度が高いことがわかり, 問題は少ないと考えられた。

\section{4. 接客面デザインの検討}

OMR 方式による自動券売機の接客面デザインについ て, 記入エラー時の修正要求表示や, 満席時の代替列車 への変更要求情報の提示などコンピュータとの対話手段 としての情報伝達方法について, モックアップにより検 討を行った.

どのような表示方法で, 記入エラーの内容を利用者に 理解させるかについて接客面のデザインについて検討す るとともに，被験者による実験により確認を行った。

記入エラーの内容表示には，修正すべき理由である欄 相違や記入もれのような表示と修正すべき箇所であるエ ラー項目があり, 前者の理由については CRT ディスプ レイを用いるととも検討したが，銀行における CDなど に使われている回転表示器を用い, その項目については 表示ランプを点燈させる方式を用いた。

また，エラー発生時の OMR カードの返却のタイミン グについても，実験によりエラー表示を理解するため に，エラ一表示後10秒経過後にカードを放出するほうが 修正箇所の理解に効果的で早く修正されることが判明し た.

\section{5. 操作性のテストによる検討}

OMR 方式による実用可能な武作機を用いて，一般の 利用者を想定した表 3 に示す 105 名の被験者により操作 性のテストを行った。 
表 3 操作性実験の被験者

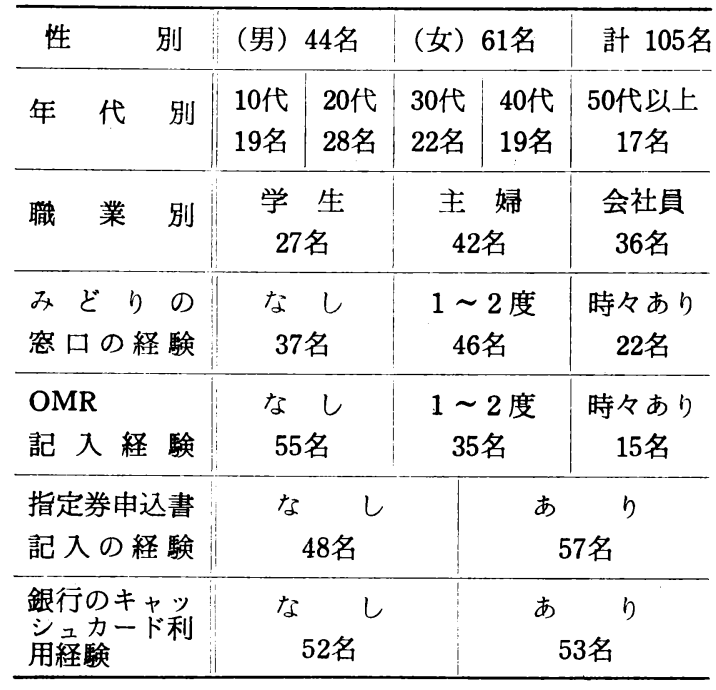

実験は前後 4 回行ったが, 初回は装置に対する予備知 識を全くもたない状態で指定券の購入の可能性をテスト するため, 一定の課題を与え，OMR カードと現金を渡 して指定券を購入させた.

OMR カードの記入時間については, 表 4 亿示すとお りで, 初回は平均 176 秒を要していた. 記入の精度につ いては, 50\%が正しく記入されていた。ささきの配票テス トの成績よりもエラーが多く発生していたが, その理由 は，記入時間を測定していたてとが心理的に影響してい たものと考えられる。

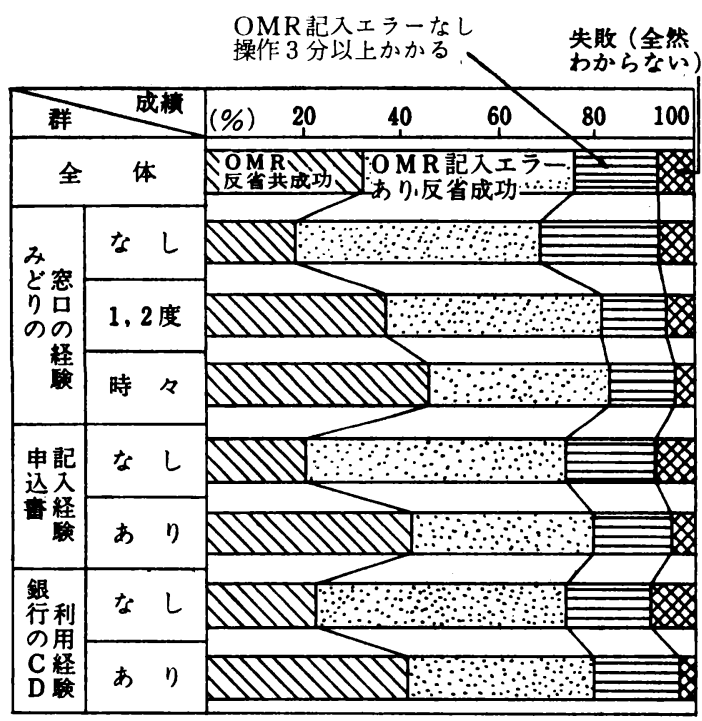

図 4 操作性実験の結果（1 回目）
衰 4 OMR カード関係の武行回数別結果

\begin{tabular}{|c|c|c|c|c|}
\hline 成 & $\begin{array}{c}\text { 記入ェラー } \\
\text { なし人員 } \\
(\%)\end{array}$ & $\begin{array}{c}\text { 記入時間 } \\
\text { (秒) }\end{array}$ & $\begin{array}{l}\text { 内容確認 } \\
\text { 時 } \\
\text { (秒) }^{\text {間 }}\end{array}$ & $\begin{array}{l}\text { カード插 } \\
\text { 入までの } \\
\text { 時間(秒) }\end{array}$ \\
\hline 1 回 & $53(50.5)$ & 176. 4 & 21.6 & 12.7 \\
\hline 2 回 & $67(63.8)$ & 135.3 & 19.4 & 5.7 \\
\hline 3 回 & $86(81.9)$ & 113. 6 & 12.3 & 6.0 \\
\hline 4 回 & $92(87.6)$ & 86. 2 & 12. 4 & 4.2 \\
\hline
\end{tabular}

注）時間は平均値

記入時間も, 記入エラーも実験回数を重ねるに応じ て, 習熟効果があり，表 4 亿示すように減少している.

操作については, 図 4 に示すように, 全体で76\%が成 功しており, 初回で全く経験のない場合でも, 現在の “みどりの空口”で指定券の購入経験を有するグループ は, 成功率が高くなっている.

また，乙の操作に比較的よく似た銀行の CD について の経験の有無が, 本装置の操作の成否にも大きく影豐し ている.

このような装置は, 一見難しそうに思われても，一度 経験すると意外に簡単で，誰にでも理解できるため， 2 回目以降はほとんどの被験者は成功しており, 所要時間 も短くなっている.

問題は, 初回の操作をどのように理解させるかであ り, 操作方法の PR に依存する部分が大きいといえる.

したがって，操作方法を覚えた利用者は，利便性を認 め, “実用化を希望する”といった意見に変わるとと が, 2 回目のアンケート調査からも明らかとなってい ろ.

\section{6. システムの効率と人間工学の役割}

前述のように OMR カード記入の信頼性のテストによ るカード様式の検討や，モック・アップによる操作性の 実験により，デザインの検討などを行ってきたが，本シ ステムは従来の自動券売機よりも，マン・マシン・イン タフェースの問題をさらに多く合んでいるため, 人間工 学の立場からの検討がきわめて重要と考えられる.

そして，てのような研究がシステムの成否に与える影 望も大きいと考えられ, システム開発の初期段階から参 画してきた.

また，本システムのように，広く不特定多数の一般大 衆を利用の対象としたシステムでは, 単に, マン・マシ ン・インタフェースの問題のみでは解消されない要素も あり, 利用者の集団である社会的な背景として利用者の 
自動化への支持率や操作に対する順応性が問題となり, 広い意味でのマン・マシン・システムの検討が必要とな ってくる. とのシステムの場合, 自動化といっても利用 者のセルフサービスを要求している面があり, サービス ダウンに結びつくといった考え方と，利用のメリットが 大きく, 多くの人が期待し, サービス向上につながると いった 2 つの考え方がある.

この考え方の相違点は, 利用に対する負担とメリット の㸾識の差により生まれてくるが，いずれにしても利用 者に対して利用のメリットが還元されるようにシステム 設計をする必要がある.

最近はコンピュータ利用システムがますます増え, 一 般社会にも浸透し，乙れに呼応して利用可能な階層も増 えつつあり, 新しい自動化システムを歓迎する人々も増 えている.

しかし，あまり高度な利用技術を必要としたり，面倒 な操作を要するシステムは敬遠されるものと考えられ， 社会的な要求にマッチしたものであるてとがシステム開 発の条件ではなかろうかと考えている.

\section{7. おわりに}

今回, 概説した指定券自動発売機は，OMR 方式を中 心に多能型のシステムであるが, 被験者によるテストに おいて, 操作の面や OMR 記入の面から考えて, 実用化 の可能性は確認できたと考えている.

今後の実用化に対する問題点など, システムの効率化 のために読者の皆さんの貴重な御教示を賜われば幸いで ある・

\section{参考文献}

1）吉岡, 他: 鉄道労働科学, 鉄道学働科研究所, 34, 1980.

2）清水, 他：鉄道サイバネ論文集, 日本鉄道サイバ ネテックス協議会, 16〜212, 1979.

3）山内, 他：鉄道サイバネ論文集, 日本鉄道サイバ ネテックス協議会, $17 \sim 805,1980$.

\section{学会誌投稿のこ案内}

編集委員会は学会誌 “人間工学” の充実のために広く会員各位からの

原著論文の投稿を歓迎致します。

表紙裏の “人間工学”誌投稿規定を参照のうえ，ご投稿下さい.

現在のところ掲載までの期間は投稿後約 9 カ月くらいです.

日本人間工学会編集委員会 